\title{
Physical and chemical characteristics of feed coal and its by-products from a Brazilian thermoelectric power
}

\author{
Juliana de C. Izidoro ${ }^{1, *}$, Caio Miranda ${ }^{1}$, Davi Castanho ${ }^{1}$, Carlos Rossati ${ }^{1}$, Felipe \\ Campello $^{1}$, Sabine Neusatz Guilhen ${ }^{1}$, Denise Alves Fungaro ${ }^{1}$ and Shaobin Wang ${ }^{2}$ (])
}

${ }^{1}$ Instituto de Pesquisas Energéticas e Nucleares, IPEN-CNEN/SP, 05508-000, Brazil

${ }^{2}$ School of Chemical Engineering, The University of Adelaide, Adelaide, Australia

\begin{abstract}
In this study, a feed coal (FC) sample was characterized by X-ray fluorescence (XRF), X-ray diffractometry (XRD), infrared spectroscopy (FTIR), thermogravimetric analysis (TGA), scanning electron microscopy (SEM), particle size distribution analysis by laser diffraction, loss on ignition (LOI), total carbon content (TC), $\mathrm{pH}$ and conductivity. FC-derived by-products (CCBs) collected at the same coal-fired power plant were: bottom ash (BA), fly ash from cyclone filter (CA) and fly ash from bag filter (FA). In addition to the techniques used for feed coal characterization, CCBs were also characterized by total surface area (by using BET method), external surface area (by using laser diffraction), cation exchange capacity (CEC), bulk density, besides leaching and solubilization tests. FC sample contains $72.2 \%$ of volatile material, of which $55.3 \%$ is total carbon content. LOI, FTIR, TGA and TC analyzes corroborated with these results. The main crystalline phases in the FC sample were found to be quartz, kaolinite and pyrite. The elements $\mathrm{As}, \mathrm{Cr}, \mathrm{Ni}$ and $\mathrm{Pb}$ were encountered in the FC sample, indicating that the use of feed coal should be monitored due to the toxic potential of these elements. The three coal ashes were classified as class $\mathrm{F}$ according to ASTM and presented similar chemical composition. Ashes enrichment factor analysis (EF) showed that $\mathrm{As}, \mathrm{Zn}$ and $\mathrm{Pb}$ concentrate mainly in fly ash from bag filter (FA). All ashes presented quartz, mullite and magnetite as crystalline phases, as well as the same functional groups, related to the presence of humidity, organic matter and Si and Al compounds. XRD, XRF, TGA, FTIR, LOI and TC techniques were correlated and confirmed the obtained results. Leaching and solubilization tests of CCBs showed that FA sample was considered hazardous and classified as class I waste, while CA and BA samples were considered non-hazardous and non-inert wastes and classified as class II-A. In this work, feed coal sample was also compared to the CCBs samples generated from it. The results showed the differences between fuel and products through the different characterization techniques. In addition to contributing to the understanding of the relationship between coal and its combustion products, this work can also help to reduce the environmental impacts caused by the CCBs disposal.
\end{abstract}

Key words: Mineral Coal; Coal Combustion By-products; Materials Characterization.

\section{INTRODUCTION}

Electric energy production in sufficient quantity to supply for the Brazilian demand is great prominence in Brazil. The water shortage in Brazil has made the energy supply even more important. According to [1], the drought in some regions of Brazil since 2013 has resulted in changes in the country's energy levels. Hydroelectric production has significantly fallen from $81 \%$ to $69 \%$ in 2013 .

Coal is the most widely used source for electric power generation. In Brazil, coal is responsible for only $2.5 \%$ of energy production [2], but this percentage tends to increase due to the operation of new power plants for supplying the growing energy demand. Brazilian coal-fired power plants have no reached a reasonable level of sustainability yet, due to the various environmental problems related to production process, emission of greenhouse gases (GHG) and disposal of solid waste, coal combustion by-productsCCBs.

According to [3], the CCBs generated in Brazilian thermal power plants are discarded in sites for low-costdisposal. The most common alternatives include open and closed landfills, abandoned mines, sedimentation ponds, sedimentation basins, etc. [4]. Such practices usually entail in a number of environmental problems, such as contamination of vegetation and rivers around the plants, unproductive use of land in addition to high maintenance costs $[5,6]$. CCBs generated after coal combustion include fly ash, bottom ash and furnace slag. Among these, fly ash has a wide application due to its pozzolanic properties for concrete and Portland cement production [5]. however, the production rate of CCBs is much high, causing most of this waste to be disposed in inappropriate places and various environmental and economic problems. Thus, the properties of feed mineral coal in thermal power plants and its by-products are important to understand the relationship between these materials and to minimize the environmental impacts caused by coal-fired power plants.

Feed coal and CCBs samples from Figueira Thermal Power Plant (FTPP), located in southern Brazil, were chosen for this study because they are the combustion

$\begin{array}{ll}\text { Received } & \text { : March 26, 2019 } \\ \text { Revised } & \text { : June 17, 2019 } \\ \text { Accepted } & \text { : July 1, 2019 }\end{array}$


residues generated in Brazilian coal-fired power plants that present the major environmental problems related to their chemical composition according to previous studies $[7,8]$. Although the FTPP coal and some of its combustion products have been studied in some works [7-17], no a systematic characterization, has been done.

The present work is to characterize, to evaluate and to correlate the physical and chemical characteristics of feed coal and combustion by-products from FTPP using several analytical techniques in order to compare these results with the samples from the same power plant after its modernization as well as to propose environmental solutions to minimize the environmental impacts caused by the CCBs disposal.

\section{MATERIALS AND METHODS}

\subsection{Area of study}

Figueira Thermal Power Plant (FTPP) is located at the municipality of Figueira, Paraná State, Brazil and belongs to the state energy company, Companhia Paranaense de Energia (COPEL). This company is currently operated by Companhia Carbonífera do Cambuí, which is also responsible for mining activities [18]. FTPP has been operated since 1963 and has 20MW of energy generation capacity, however, it has been generated only 10.3 MW of energy on average [19].

This power plant will be expanded to increase the average electric energy to around 17.4 MW. The coal consumption will be the same asd today ( $6500 \mathrm{t} / \mathrm{month})$, but with a new technology [19].

\subsection{Coal and ash samples}

The mineral coal used in FTPP is bituminous [6]. After mining from the underground located near the power plant, the coal is processed to reduce the contents of pyrite and other inorganic compounds milled and placed into the furnace, where it will be burned with atmospheric air. The last stage of coal grinding occurs in the pulverizer and the collected sample from the pulverizer was used as feed coal and labelled as FC.

After the coal burning, three different types of coal combustion products (CCBs), bottom ash (BA), fly ash from cyclone filter (CA) and fly ash from bag filter (FA) were collected.

The bottom ash, in the largest particle size, falls down in a container of water on the bottom of the furnace and is withdrawn from the system. Cyclone filter fly ash at intermediate particle size is collected by a cyclone filter. The smallest particle size ashes (fly ashes) are retained by a bag filter after the cyclone filter. Figure 1 summarizes the coal ash retention systems used in FTPP.

\subsection{Characterization}

\subsubsection{Chemical composition}

The chemical composition of feed coal and CCBs were determined by X-ray fluorescence (XRF) in a Bruker S8 Tiger equipment.

\subsubsection{Total carbon content}

Total carbon content was determined by a LECO analyzer (model CS-400) with a radio frequency furnace (model HF-400A). Firstly, a sample was placed in an alumina crucible and burnt under oxygen atmosphere ( $99.9 \%$ of purity) in a radio frequency furnace, generating $\mathrm{CO}$ and $\mathrm{CO}_{2}$ gases. Subsequently, all $\mathrm{CO}$ was converted into $\mathrm{CO}_{2}$ by a catalyst, and the total quantity of $\mathrm{CO}_{2}$ was determined by an infrared detector [20].

\subsection{3 $\mathrm{pH}$ and conductivity}

The $\mathrm{pH}$ and the conductivity were measured as follows: samples $(0.25 \mathrm{~g})$ were placed in $25 \mathrm{~mL}$ of deionized water and the mixture was stirred for $24 \mathrm{~h}$ in a shaker at $120 \mathrm{rpm}$ (Ética - Mod 430). After filtration, the $\mathrm{pH}$ of the solutions was measured with a $\mathrm{pH}$ meter (MSTecnopon - Mod MPA 210) and the conductivity was measured with a conductivimeter (BEL Engineering-Mod W12D) [21, 22].

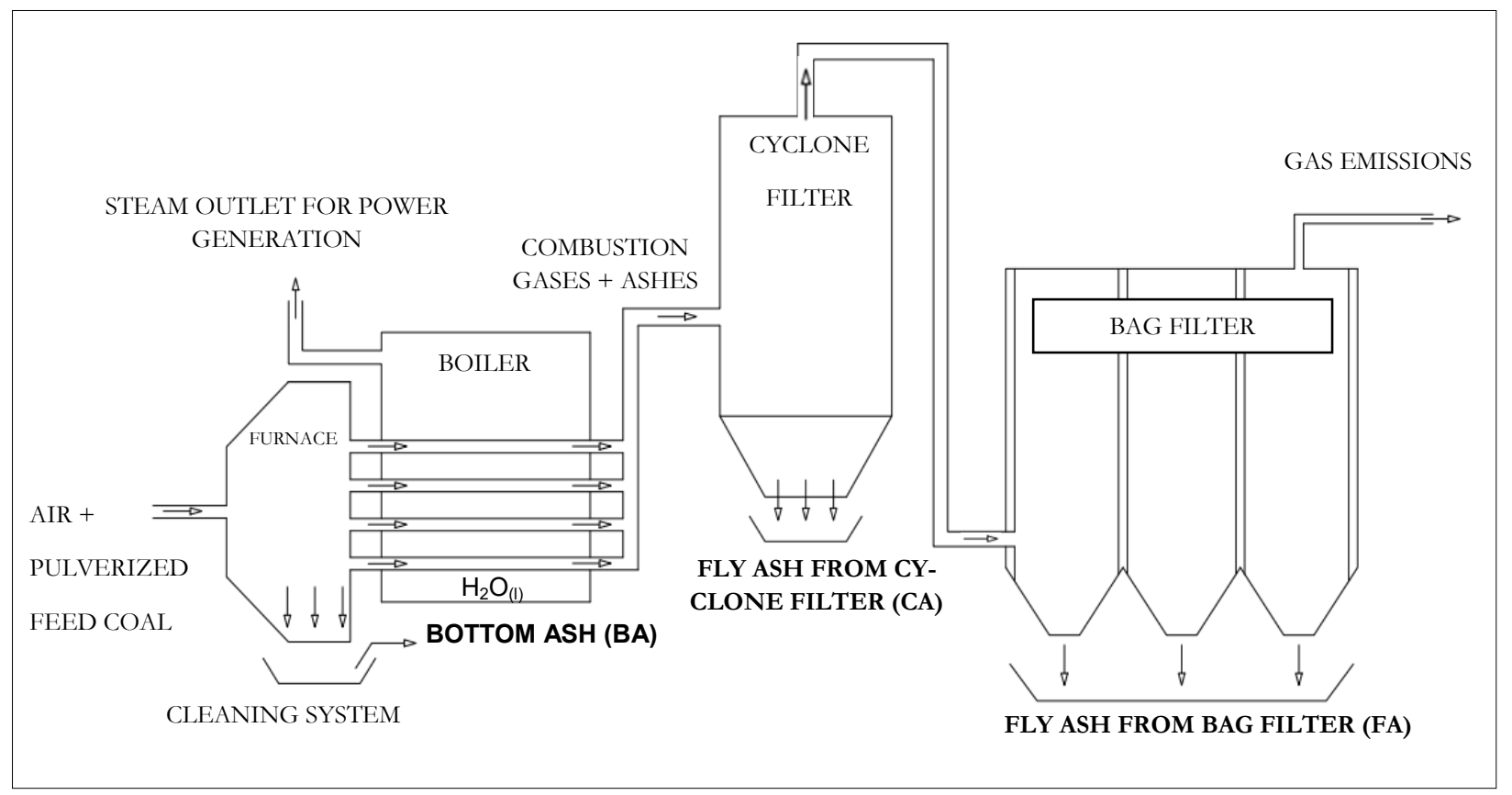

Fig. 1. FTPP coal ash retention systems scheme. 


\subsubsection{Loss on ignition}

The content of loss on ignition (LOI) of feed coal and CCBs were calculated according to the weight loss on the samples subjected to heating at $1020^{\circ} \mathrm{C}$ for $2 \mathrm{~h}$ in a muffle furnace and expressed in percentages.

\subsubsection{Bulk density}

The bulk density of zeolitic materials was calculated from the weight of each sample divided by the volume of 35 $\mathrm{mL}$ of the sample in a beaker.

\subsubsection{Determination of the specific surface area by gas adsorption}

The $\mathrm{N}_{2}$ adsorption measurements of the samples were carried out using a Micromeritics Adsorption Analyzer, model ASAP 2010. Prior to measurements, samples were heated at $120{ }^{\circ} \mathrm{C}$ for $8 \mathrm{~h}$ under vacuum conditions to remove volatiles and moisture. The BET surface areas were obtained by applying the BET equation to the nitrogen adsorption data.

\subsubsection{Cation exchange capacity (CEC)}

In Cation Exchange Capacity measurements (CEC), the samples were saturated with sodium acetate solution (1 mol L $\left.\mathrm{L}^{-1}\right)$, washed with distilled water $(1 \mathrm{~L})$ and then mixed with ammonium acetate solution $\left(1 \mathrm{~mol} \mathrm{~L}^{-1}\right)$. The sodium ion concentration of the resulting solution was determined by optical emission spectrometry with inductively coupled plasma - ICP-OES (Spectro - Arcos).

\subsubsection{Morphlogy}

The morphology of feed coal and CCBs was verified by a scanning electron microscope (Philips - XL30). Samples were covered with a thin layer of gold to make them conductive prior to observations in the microscope.

\subsubsection{Mineralogical composition}

The mineralogical compositions of samples were determined by X-ray diffraction (Rigaku - Multiflex II $\mathrm{X}$-ray Diffractometer) using $\mathrm{Cu} \mathrm{Ka}$ radiation at $40 \mathrm{kV}$ and 20 $\mathrm{mA}$. The scan rate was $0.02 \% \mathrm{~s}$ and ranged between $5-90$ $\circ(2 \theta)$. Crystalline phase identification was made by using the Search-Match computer program and by searching the ICDD powder diffraction file database, with the help of JCPDS (Joint Committee on Powder Diffraction Standards) files for inorganic compounds. Rietveld refinement method was used to quantify the mass percentage of each crystalline phase for each sample. The crystallographic data were analyzed by using the Find It program. The General Structure Analysis System program (GSAS) was used to refine the phases.

\subsubsection{Functional groups identification}

The functional groups present in the coal and in the ash samples were determined by the Fourier Transform Infrared (FTIR) absorption spectroscopy technique using Thermo-Nicolet equipment, model Nexus 670, with a range of $4000 \mathrm{~cm}^{-1}$ at $400 \mathrm{~cm}^{-1}$. Samples were prepared by dissolving the sample itself with $\mathrm{KBr}$ (previously oven dried and used as diluent) until a homogeneous mixture was obtained. The solid mixture was pressed to form a pellet and submitted to the equipment.

\subsubsection{Thermal analysis}

Sample mass variation as a function of temperature was evaluated by Thermo Gravimetric Analysis (TGA) using the TGA thermogravimetric analyzer SDTA 851 - Mettler Toledo. For the feed coal, a mass of $9.3 \mathrm{mg}$ of the previously dried sample was heated using a rate of $10^{\circ} \mathrm{C} \mathrm{min}^{-1}$ in an inert nitrogen atmosphere with a flow of $50 \mathrm{~mL} \mathrm{~min}^{-1}$, and followed by an isotherm at $1200^{\circ} \mathrm{C}$ in an oxygen atmosphere during $15 \mathrm{~min}$ [23]. For the ashes, $7 \mathrm{mg}$ of each sample was previously dried and analyzed under a dynamic

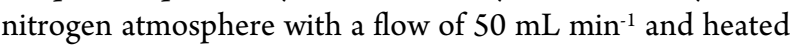
until reach $1200^{\circ} \mathrm{C}$ using a rate of $10^{\circ} \mathrm{C} \mathrm{m^{-1 }}$.

\subsubsection{Particle size analysis}

The particle size distribution for the samples was determined using a laser diffraction particle size analyzer (Malvern Instruments - Version 5.54). Isopropyl alcohol was used as a dispersing medium. The working range of particle size was 0.1 to $1000 \mu \mathrm{m}$.

\subsubsection{Leaching and solubilization tests}

The ashes environmental classification was carried out by leaching and solubilization tests according to the Brazilian regulations NBR 10005: 2004 and NBR 10006: 2004, respectively. For the leaching tests, $10 \mathrm{~g}$ of coal ash sample was stirred with an acetic acid solution $(\mathrm{pH} 4.93 \pm$ 0.05 ) for $18 \mathrm{~h}$ at $30 \mathrm{rpm}$ (Ética - Mod. 430 Agitator). After filtration, the leachable compounds were extracted, and the elements of interest were analyzed [24]. For the solubilization tests, $25 \mathrm{~g}$ of coal ash sample was placed in contact with $100 \mathrm{~mL}$ of ultrapure water. The suspension was stirred for $5 \mathrm{~min}$ and after it was allowed to stand for seven days at room temperature. After filtration, the solubilized extracts were analyzed [25]. For both the leaching and solubilization tests, the concentration of $\mathrm{Hg}$ was determined by graphite furnace atomic absorption cold vapor spectrometry (CV-AAS-PerkinElmer - A Analyst 800 ) while the concentrations of all others elements were determined by inductively coupled plasma optical emission spectrometry (ICP-OES - Spetro - Arcos). The $\mathrm{pH}$ and the conductivity in all extracts were also determined.

\section{RESULTS AND DISCUSSION}

\subsection{Feed coal characterization}

Table 1 Characteristics of feed mineral coal used for electric power generation at the Figueira Thermoelectric Power Plant - FTPP.

\begin{tabular}{lcc}
\hline \multicolumn{1}{c}{$\begin{array}{c}\text { Characteristics } \\
\text { (FC) }\end{array}$} & $\begin{array}{c}\text { Obtained } \\
\text { Values }\end{array}$ & Reference \\
\hline Loss on ignition & $72.2 \%$ & Present work \\
Total carbon & $55.32 \%$ & Present work \\
$\mathrm{pH}$ & 6.71 & $\begin{array}{c}\text { Present work } \\
\text { Conductivity }\end{array}$ \\
Fixed carbon & $77 \mu \mathrm{S}$ & $\begin{array}{c}\text { Present work } \\
\text { UTFG }\end{array}$ \\
& $43 \%$ & Collection \\
Calorific value & $4.780 \mathrm{kCal} / \mathrm{kg}$ & UTFG \\
Ash content & & Collection \\
& $26 \%$ & UTFG \\
& & Collection \\
Humidity content & $10 \%$ & UTFG \\
& & Collection
\end{tabular}


The physical and chemical characteristics of the feed coal used for electric energy generation in Figueira Thermal Power Plant (FTPP) are shown in Table 1. According to Table 1, feed coal presented loss on ignition of $72.2 \%$, related to the volatile matter which contains hydrocarbons and other light chemical elements in its composition, such as nitrogen, sulfur, and oxygen. These components are converted in combustion gases when mineral coal is burnt. Total carbon content was $55.32 \%$. This amount represents all carbon in the sample which can be converted to $\mathrm{CO}_{2}$, including organic carbon. According to [26], Brazilian coal samples from Butiá, Jacuí, Tubarão and Criciúma mines presented total carbon content of $42.88 \%, 49.82 \%, 40.79 \%$ e $46.90 \%$, respectively. Thus, feed coal from FTPP presented higher total carbon content when compared to the coal from mines from other parts of Brazil. This factor can contribute to the generation of a greater quantity of electricity, making the thermal plant more efficient. Fixed carbon which is the remaining residue after combustion of coal without the volatile compounds was $43 \%$ for FC sample.

The calorific value of FC was $4.780 \mathrm{kCal} / \mathrm{kg}$. According to [26], $\mathrm{C}$ and $\mathrm{H}$ are the main elements that contribute to that parameter, whereas the presence of oxygen decreases the calorific value as well as the necessity of combustion air. Thus, the content of carbon in the coal is directly related to the calorific value, accordingly, coal with a high content of carbon can also present a high calorific value. On the other hand, coal with a high content of humidity and ash is considered as lower quality.

According to Table 1, the $\mathrm{pH}$ of $\mathrm{FC}$ was 6.71 . This $\mathrm{pH}$ is related to the soil acidity from Figueira region, from where the coal is extracted [27]. The conductivity value was $77 \mu \mathrm{S}$. This parameter is related to the elements which can be dissolved, as metals and other inorganic compounds, which are shown later in chemical and mineralogical composition of coal (Table 2 and Figure 2, respectively). The higher the organic matter content in coal, the higher its calorific value, and therefore the lower its conductivity. The ash content from feed coal was $26 \%$, which is considered high when compared to the ash content from other Brazilian coal samples $[28,29]$. The humidity content was $10 \%$. According to [26], water is usually found in all fuels, particularly in solid fuels, in the form of humidity, and results in a decrease in calorific power besides corrosion-related problems. The chemical composition of feed coal (FC) from FTPP obtained by X-ray fluorescence (XRF) is given in Table 2.

According to Table 2, $\mathrm{FC}$ is mainly composed by $\mathrm{SiO}_{2}$, $\mathrm{Al}_{2} \mathrm{O}_{3}, \mathrm{SO}_{3}$ e $\mathrm{Fe}_{2} \mathrm{O}_{3}$, with a content of $13.0 \%$, 5.59\%, 4.94\%, and $2.05 \%$, respectively. Quantities below $1 \%$ of $\mathrm{K}_{2} \mathrm{O}, \mathrm{CaO}$, $\mathrm{MgO}, \mathrm{TiO}_{2}$, and $\mathrm{Na}_{2} \mathrm{O}$ are also observed. Other metallic elements such as zinc, manganese, lead, copper, chromium, zirconium and strontium may also be present in coal. The chemical composition of feed coal from FTPP is in accordance with other research both from Figueira coal samples and other research both from Figueira coal samples and from other sources $[7,30]$. As, $\mathrm{Cr}, \mathrm{Ni}$, and $\mathrm{Pb}$ are considered toxic, thus, their presence in coal needs to be monitored in order to avoid environmental pollution both in the air, where they can be released together with the combustion gases, and also in the solid wastes, where those elements can concentrate [31]. Elements as $\mathrm{Hg}$ and $\mathrm{U}$ were not determinate in this study, but they can usually be encountered in feed coal samples from Figueira Power Plant $[7,9]$.

Table 2 Chemical composition (wt\%) of feed coal sample from FTPP

\begin{tabular}{|c|c|}
\hline Components & $\mathrm{FC}$ \\
\hline $\mathrm{SiO}_{2}$ & 13.0 \\
\hline $\mathrm{Al}_{2} \mathrm{O}_{3}$ & 5.59 \\
\hline $\mathrm{SO}_{3}$ & 4.94 \\
\hline $\mathrm{Fe}_{2} \mathrm{O}_{3}$ & 2.05 \\
\hline $\mathrm{K}_{2} \mathrm{O}$ & 0.69 \\
\hline $\mathrm{CaO}$ & 0.581 \\
\hline $\mathrm{MgO}$ & 0.317 \\
\hline $\mathrm{TiO}_{2}$ & 0.259 \\
\hline $\mathrm{Na}_{2} \mathrm{O}$ & 0.233 \\
\hline $\mathrm{ZnO}$ & 0.062 \\
\hline $\mathrm{P}_{2} \mathrm{O}_{5}$ & 0.019 \\
\hline $\mathrm{MnO}$ & 0.016 \\
\hline $\mathrm{PbO}$ & 0.005 \\
\hline $\mathrm{SrO}$ & 0.004 \\
\hline $\mathrm{CuO}$ & 0.004 \\
\hline $\mathrm{As}_{2} \mathrm{O}_{3}$ & 0.011 \\
\hline $\mathrm{ZrO}_{2}$ & 0.011 \\
\hline $\mathrm{Cr}_{2} \mathrm{O}_{3}$ & 0.01 \\
\hline $\mathrm{Y}_{2-} \mathrm{O}_{3}$ & $<0.001$ \\
\hline $\mathrm{NiO}$ & $<0.001$ \\
\hline $\mathrm{Rb}_{2} \mathrm{O}$ & $<0.001$ \\
\hline $\mathrm{V}_{2} \mathrm{O}_{5}$ & $<0.001$ \\
\hline $\mathrm{MoO}_{3}$ & $<0.001$ \\
\hline $\mathrm{BaO}$ & $<0.001$ \\
\hline
\end{tabular}

Light elements as $\mathrm{H}, \mathrm{Li}, \mathrm{Be}, \mathrm{B}, \mathrm{C}, \mathrm{N}$ e $\mathrm{O}$ were not identified by the $\mathrm{X}$-ray fluorescence equipment used in this study but their presence can be detected by using other characterization techniques such as loss on ignition and total carbon content (Table 1), infrared absorption spectroscopy (Figure 3) and thermal analysis (Figure 4), which will be discussed later.

Silicon, sulfur, iron and aluminum contents are related to mineral phases of quartz, pyrite, and kaolinite present in the sample. These crystalline phases obtained by $\mathrm{X}$ -ray diffraction (XRD) can be observed in Figure 2. The XRD Patterns, chemical formulas and mass percentage of the different crystalline phases identified in the feed coal sample are shown in Table 3.

In addition to the three identified crystalline phases, Figure 2 indicates the presence of amorphous content in FC through the elevation of the baseline between angles 5 and $30^{\circ} 2 \theta$. That amorphous phase is related to carbon, organic matter, and other inorganic compounds contents present in the sample.

Table 3 shows that Kaolinite was present in a higher percentage $(62.3 \%)$, followed by quartz $(31.5 \%)$ and pyrite (6.2\%). Pyrite content is in accordance with [31], which 
attributes a content for this mineral estimated around $7 \%$ for Figueira coal. The crystalline phases identified in FC sample are in accordance with the results presented by [28] and [23] which have studied Brazilian coal samples.

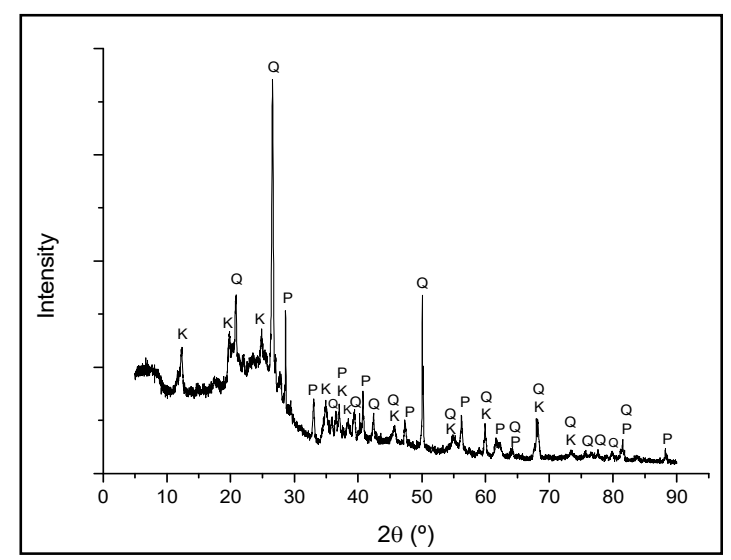

Fig. 2. XRD Patterns of feed coal sample $(\mathrm{Q}=$ Quartz, $\mathrm{P}=$ Pyrite and $\mathrm{K}=$ Kaolinite).

Table 3 XRD Patterns, chemical formulas and mass percentage of the different crystalline phases identified in the feed coal sample (FC).

\begin{tabular}{cccc}
\hline $\begin{array}{c}\text { Crystalline } \\
\text { Phases }\end{array}$ & $\begin{array}{c}\text { XRD } \\
\text { Pattern }\end{array}$ & $\begin{array}{c}\text { Chemical } \\
\text { formula }\end{array}$ & Percentage \\
\hline Kaolinite (K) & $74-1784$ & $\begin{array}{c}\mathrm{Al}_{2} \mathrm{Si}_{2} \mathrm{O}_{5} \\
(\mathrm{OH})_{4}\end{array}$ & $62.3 \%$ \\
Quartz (Q) & $83-539$ & $\mathrm{SiO}_{2}$ & $31.5 \%$ \\
Pyrite (P) & $42-1340$ & $\mathrm{FeS}_{2}$ & $6.2 \%$ \\
\hline
\end{tabular}

It is important to highlight that the mass percentages obtaine by the Rietveld Method (Table 3) were calculated without the amorphous phase. This analysis was only done for comparison between the samples so that the sum of the percentages of the crystalline phases was $100 \%$. The morphology of the CA sample verified by a scanning electron microscope (SEM) is shown in Figure 3.

According to Figure 3, FC sample is formed of particles of varying sizes and shapes. This morphology is related to the presence of the different compounds showed in chemical and mineralogical composition analysis.

Figure 4 shows the functional groups present in the feed coal, identified by FTIR absorption spectroscopy technique. The bands at $3619.66 \mathrm{~cm}^{-1}$ and $3405.60 \mathrm{~cm}^{-1}$ are attributed to free water and hydration water, respectively. The presence of organic matter is related to bands at $2920.31 \mathrm{~cm}^{-1}$ and $1384.30 \mathrm{~cm}^{-1}$, which refer to axial and angular deformations of $\mathrm{C}-\mathrm{H}$ bonds of aliphatic groups, respectively, as well as the bands at $1598.03 \mathrm{~cm}^{-1}$ and 912.40 $\mathrm{cm}^{-1}$, which refer to axial and angular deformations of $\mathrm{C}=\mathrm{C}$ bonds of alkenes. The bands at $1030.37 \mathrm{~cm}^{-1}$ and $533.16 \mathrm{~cm}^{-1}$ could be assigned to characteristic bonds of $\mathrm{O}-\mathrm{Si}-\mathrm{O}$ groups, for axial and angular deformations, respectively. The bands at $777 \mathrm{~cm}^{-1}$ and $466.64 \mathrm{~cm}^{-1}$ are attributed to the symmetrical stretching vibration and asymmetrical stretching vibration of the O-T-O groups, respectively, where $\mathrm{T}$ represents $\mathrm{Si}$ or $\mathrm{Al}$ present in the crystalline phases of quartz and kaolinite.
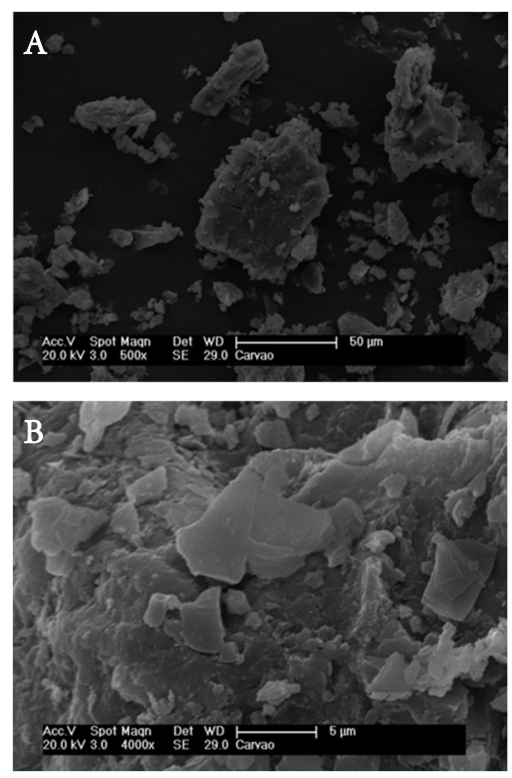

Fig. 3. Scanning Electron Micrographs (SEM) of feed coal (FC): a) Size: $500 \mathrm{X}$; b) Size: 4000X.

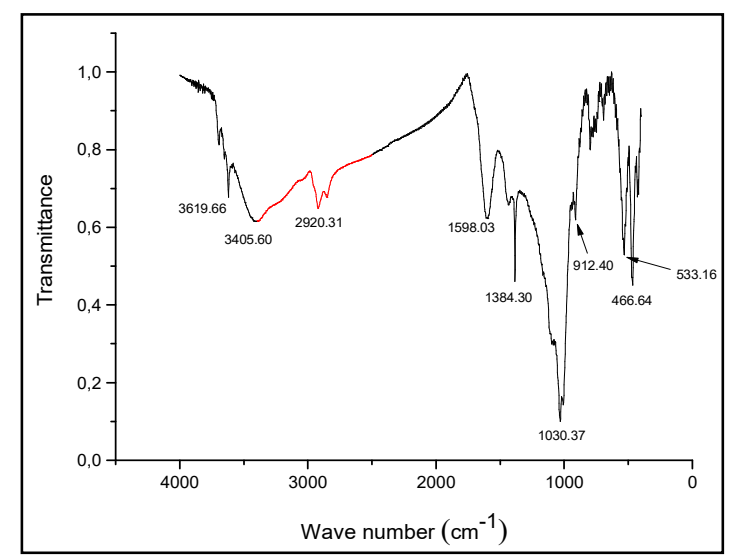

Fig. 4. FTIR spectra of feed coal sample (FC).

The functional groups identified by FTIR corroborate with the results of the chemical and mineralogical analysis (Tables 2 and 3). The presence of the amorphous phase, for example, discussed at the XRD results was confirmed by the presence of $\mathrm{C}-\mathrm{H}$ and $\mathrm{C}=\mathrm{C}$ functional groups identified by FTIR. In addition, the amount of organic matter present in the coal is reflected in the loss on ignition (LOI) results showed in Table 1.

The TGA and DTG diagrams of FC sample obtained by Thermo Gravimetric Analysis (TGA) using the TGA thermogravimetric analyzer are shown in Figure 5 . According to Figure 5, TGA curve shows a small decrease in weight related to moisture loss $(1.0 \%)$, followed by a loss of volatile material between 440 and $523{ }^{\circ} \mathrm{C}(15.93 \%)$ and a loss of organic matter between $523{ }^{\circ} \mathrm{C}$ and $1199{ }^{\circ} \mathrm{C}$ (26.47\%). These first weight losses occurred in an inert atmosphere $\left(\mathrm{N}_{2}\right)$. When the sample was placed in an oxidizing atmosphere (from $1200{ }^{\circ} \mathrm{C}$ ), there was a rapid weight loss of $29.8 \%$, related to the combustion of fixed carbon present in feed coal. According to [23], the peak at $440^{\circ} \mathrm{C}$ in DTG curve can be attributed to the pyrolysis process of the compounds with structures less stable usually present in Brazilian coal samples as well as the thermal 
decomposition of pyrite (identified by XRD - Figure 2).

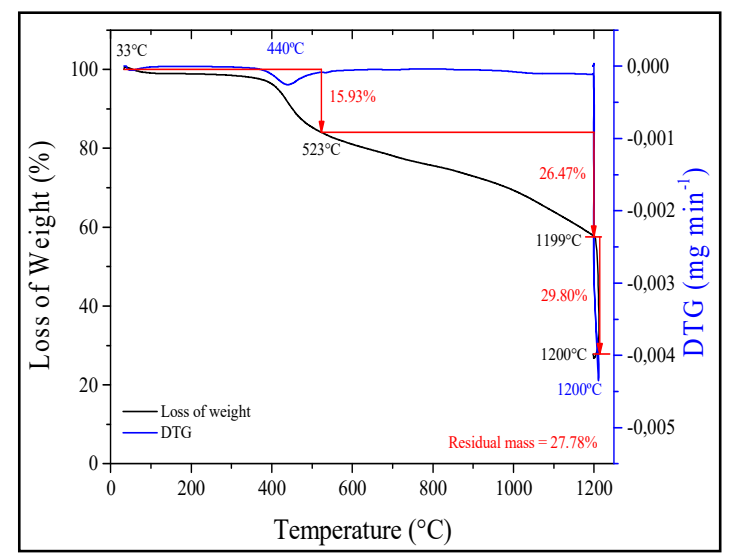

Fig. 5. TGA-DTG diagrams of pulverized feed coal (FC).

The weight loss of FC sample caused by the loss of organic matter $(26.47 \%)$ together with the weight loss related to the content of fixed carbon at $1200{ }^{\circ} \mathrm{C}(29.8 \%)$ corroborates to the content of total carbon determined for this sample (55.32\% - Table 1), showing that these two techniques can be complementary in the characterization study of coal. In addition, TGA-DTG analysis also confirms the results of loss on ignition obtained for FC sample $(72.2 \%$ - Table 1$)$, which is related to the loss of volatile matter, organic matter and fixed carbon, with weight losses of $15.93 \%, 26.47 \%$, and $29.8 \%$, respectively. The residual mass of the sample $(27.78 \%)$ refers to the content of the remaining inorganic material or ashes, and it is similar to the result of the ash content of the coal that feeds Figueira Power Plant, showed in Table 1 (26\%).

The results of the particle size distribution of the feed coal sample determined by using a laser diffraction particle size analyzer can be observed in both Figure 6 and Table 4 .

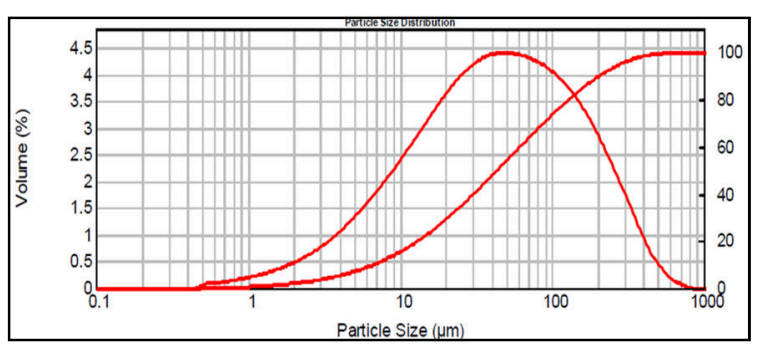

Fig. 6. Particle size distribution of feed coal sample (FC).

Sauter diameter $\left(D_{3.2}\right)$ is the average diameter calculated by the equipment based on the average surface area of the particles and it is very important for studies of a surface. The $\mathrm{D}_{4.3}$ diameter is the average diameter based on the average volume of the particles and can be related to the burning efficiency of coal in the thermal plant. According to Table 4, the $\mathrm{D}_{3.2}$ and $\mathrm{D}_{4.3}$ values for FC sample were 14.888 $\mu \mathrm{m}$ and $79.308 \mu \mathrm{m}$, respectively. The shape of the curve observed in Figure 6 shows that the particle size distribution follows a normal distribution, thus the average particle diameter of FC coal can be considered to be close to the $\mathrm{D}_{50}$, and therefore around $43.357 \mu \mathrm{m}$.
Table 4 Particle size distribution analysis of FC sample

$\begin{array}{ll}\begin{array}{l}\text { Sauter mean diameter } \\ \left(D_{3.2}-\mu \mathrm{m}\right)\end{array} & 14.888 \\ \begin{array}{l}\text { Mean diameter related to } \\ \text { particles volume }\left(D_{4.3-}\right. \\ \mu \mathrm{m})\end{array} & 79.308 \\ \begin{array}{l}\text { Diameter below which } \\ 50 \% \text { of the particles are } \\ \text { present }\left(\mathrm{D}_{50}-\mu \mathrm{m}\right)\end{array} & 43.357 \\ \begin{array}{l}\text { Diameter below which } \\ \text { 90\% of the particles are } \\ \text { present }\left(\mathrm{D}_{90}-\mu \mathrm{m}\right)\end{array} & 203.287\end{array}$

\subsection{Coal Combustion By-products (CCBs) characterization}

\subsubsection{Chemical composition}

The determination of the chemical composition of the coal combustion residues is very important to study the most convenient and less aggressive disposition method to the environment as well as to study the potential applications of these by-products. The chemical compositions of the CCBs (by \% weight) determined by $\mathrm{X}$ -ray fluorescence (XRF) are given in Table 5.

Table 5 Chemical composition (wt\%) of coal ash samples

\begin{tabular}{|c|c|c|c|}
\hline Components & $\mathrm{BA}$ & CA & FA \\
\hline $\mathrm{SiO}_{2}$ & 45.4 & 46.0 & 49.2 \\
\hline $\mathrm{Al}_{2} \mathrm{O}_{3}$ & 17.0 & 16.2 & 21.6 \\
\hline $\mathrm{Fe}_{2} \mathrm{O}_{3}$ & 10.2 & 13.2 & 9.86 \\
\hline $\mathrm{CaO}$ & 2.76 & 3.57 & 2.06 \\
\hline $\mathrm{K}_{2} \mathrm{O}$ & 2.46 & 2.20 & 2.74 \\
\hline $\mathrm{SO}_{3}$ & 1.46 & 1.54 & 1.65 \\
\hline $\mathrm{TiO}_{2}$ & 0.863 & 0.86 & 1.20 \\
\hline $\mathrm{MgO}$ & 0.936 & 0848 & 1.02 \\
\hline $\mathrm{Na}_{2} \mathrm{O}$ & 0.942 & 1.01 & 1.23 \\
\hline $\mathrm{ZnO}$ & 0.136 & 0.222 & 0.682 \\
\hline $\mathrm{MnO}$ & 0.084 & 0.099 & 0.061 \\
\hline $\mathrm{P}_{2} \mathrm{O}_{5}$ & 0.039 & $<0.001$ & 0.097 \\
\hline $\mathrm{Cr}_{2} \mathrm{O}_{3}$ & 0.055 & 0.062 & 0.048 \\
\hline $\mathrm{PbO}$ & $<0.001$ & 0.02 & 0.049 \\
\hline $\mathrm{As}_{2} \mathrm{O}_{3}$ & 0.026 & 0.034 & 0.16 \\
\hline $\mathrm{ZrO}_{2}$ & 0.063 & 0.067 & 0.099 \\
\hline $\mathrm{Rb}_{2} \mathrm{O}$ & 0.012 & 0.011 & 0.014 \\
\hline $\mathrm{SrO}$ & 0.02 & 0.022 & 0.029 \\
\hline $\mathrm{NiO}$ & $<0.001$ & 0.009 & 0.011 \\
\hline $\mathrm{CuO}$ & 0.012 & 0.015 & 0.022 \\
\hline $\mathrm{Y}_{2-} \mathrm{O}_{3}$ & 0.016 & $<0.001$ & 0.028 \\
\hline $\mathrm{V}_{2} \mathrm{O}_{5}$ & 0.06 & 0.053 & 0.082 \\
\hline $\mathrm{MoO}_{3}$ & 0.014 & 0.016 & 0.03 \\
\hline $\mathrm{BaO}$ & 0.038 & $<0.001$ & $<0.001$ \\
\hline $\mathrm{SiO}_{2} / \mathrm{Al}_{2} \mathrm{O}_{3}$ & 2.47 & 2.57 & 2.19 \\
\hline
\end{tabular}


There were no significant variations among the contents of the main oxides present in the ashes. The sum of main oxides $\left(\mathrm{SiO}_{2}+\mathrm{Al}_{2} \mathrm{O}_{3}+\mathrm{Fe}_{2} \mathrm{O}_{3}\right)$ was 72.6, 75.4 and $80.7 \%$ for BA, CA and FA, respectively. These ashes were classified as Class $\mathrm{F}$ type according to the American Society for Testing and Materials (ASTM C618). The contents of Si and $\mathrm{Al}$ were above $60 \%$ for all samples indicating that these materials can be used for the synthesis of alternative adsorbent materials $[8,10,32-34]$. The contents of $\mathrm{CaO}$, $\mathrm{K}_{2} \mathrm{O}$, and $\mathrm{SO}_{3}$ were between 1.5 and $3.6 \%$. The iron and sulfur compounds $\left(\mathrm{Fe}_{2} \mathrm{O}_{3}\right.$ and $\left.\mathrm{SO}_{3}\right)$ are derived from the pyrite $\left(\mathrm{FeS}_{2}\right)$ usually present in the feed coal (determined by $\mathrm{XRD}$ - Figure 2). The presence of S in CCBs shows that not all the sulfur present in the pyrite can be converted into $\mathrm{SO}_{2}$ and $\mathrm{SO}_{3}$ gases after the coal combustion. Low variations in the amounts of the presented compounds can occur due to the different exposure time of each waste to the heat from the flue gas that comes from the furnace, which allows that some volatile elements to separate from the solid phase and migrate to the gaseous phase. The $\mathrm{SiO}_{2} / \mathrm{Al}_{2} \mathrm{O}_{3}$ ratios were calculated for coal ashes and the values ranged from 2.19 to 2.57 . These values are consistent with other studies $[4,35]$.

In order to understand how the main elements present in the coal behave during the combustion, in which type of waste they are more likely to concentrate and which elements are more or less volatile, the Enrichment Factor (EF) was calculated. Through EF, the concentrations of the different elements can be normalized using as reference a non-volatile element for which their concentration is known in both coal and ash. The use of EF is more convenient than the direct comparison between the concentrations of the elements. The non-volatile elements most used in this calculation are $\mathrm{Al}, \mathrm{Ce}, \mathrm{Fe}, \mathrm{Si}$, and $\mathrm{Ti}$, among others. In the present study, $\mathrm{Al}$ was chosen as the non-volatile element $[28$, 29]. The EF was calculated for bottom ash $\left(\mathrm{EF}_{\mathrm{BA}}\right)$, for the ash from cyclone filter $\left(\mathrm{EF}_{\mathrm{CA}}\right)$, and for the fly ash from bag filter $\left(\mathrm{EF}_{\mathrm{FA}}\right)$ by equations (1), (2) and (3), respectively:

$$
\begin{aligned}
& \mathrm{EF}_{\mathrm{BA}}=\left[\mathrm{C}_{\mathrm{oBA}} / \mathrm{CAl}_{\mathrm{BA}}\right] /\left[\mathrm{C}_{\mathrm{oCoal}} / \mathrm{CAl}_{\text {Coal }}\right] \\
& \mathrm{EF}_{\mathrm{CA}}=\left[\mathrm{C}_{\mathrm{oCA}} / \mathrm{CAl}_{\mathrm{CA}}\right] /\left[\mathrm{C}_{\mathrm{oCoal}} / \mathrm{CAl}_{\text {Coal }}\right] \\
& \mathrm{EF}_{\mathrm{FA}}=\left[\mathrm{C}_{\mathrm{oFA}} / \mathrm{CAl}_{\mathrm{FA}}\right] /\left[\mathrm{C}_{\mathrm{oCoal}} / \mathrm{CAl}_{\text {Coal }}\right]
\end{aligned}
$$

Where, $\mathrm{C}_{\mathrm{o}}$ is the concentration of a given element and $\mathrm{CAl}$ is the concentration of aluminum in the concerned waste (BA, CA or FA) or in the feed coal $[28,29,36]$. By using this normalization system, the enriched elements in the ashes will reach an EF $>1$. On the other hand, the most impoverished elements will have an EF $<1$ [29]. A comparison among the EFs determined for each ash can also be made to verify in which waste the concerned element concentrates more and verify its volatilization. Figure 7 shows the EFs calculated for the different chemical elements present in the ashes.

According to Figure 2, the elements enriched in the fly ash from bag filter (which presented EF $>1$ ) in descending order were as follows: As $(\mathrm{FE}=3.8), \mathrm{Zn}(2.8)$, $\mathrm{Pb}(2.5), \mathrm{Zr}(2,3), \mathrm{Sr}(1,9), \mathrm{Cu}$ and $\mathrm{Na}(1,4), \mathrm{P}(1,3), \mathrm{Fe}$, $\mathrm{Ti}$, and $\mathrm{Cr}(1,2)$. The three elements which presented the highest $\mathrm{EF}$ in the fly ash (As, $\mathrm{Zn}$ and $\mathrm{Pb}$ ) were impoverished in bottom ash (EF of $0.8,0.7$ and 0 for the elements, respectively), but presented an intermediate value (and higher than 1.0) for the cyclone ash. These results indicate that those elements are still volatile at the cyclone filter temperature and condense inside the bag filter when the temperature decreases, concentrating on the ashes with a smaller particle size (FA). CA sample presented EF $>1$ for the following elements: $\mathrm{Fe}, \mathrm{K}, \mathrm{Ca}, \mathrm{Ti}, \mathrm{Na}, \mathrm{Zn}, \mathrm{Sr}, \mathrm{Mn}, \mathrm{Pb}$, $\mathrm{Cu}$, As, $\mathrm{Zr}$ and $\mathrm{Cr}$. Most of these elements are also concentrated in the FA sample and are depleted in the BA sample, with the exception of $\mathrm{Ca}$ and $\mathrm{Mn}$, which concentrated more in the CA sample.

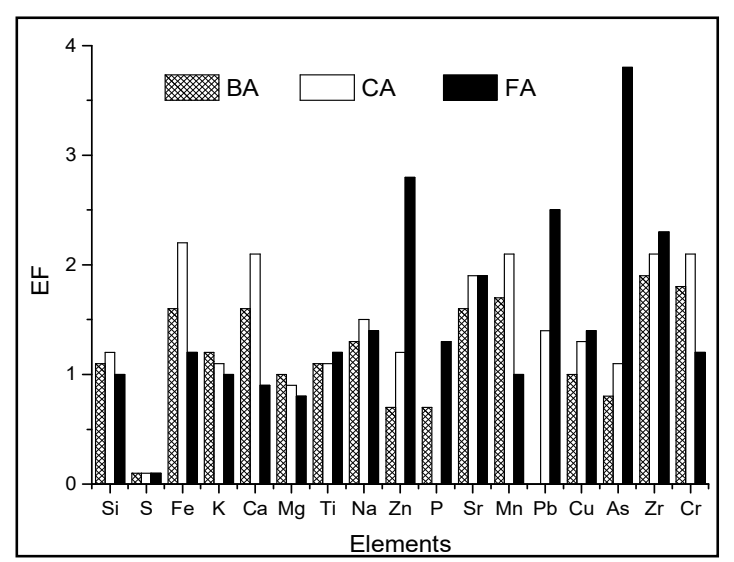

Fig. 7. Enrichment Factor (EF) to the main elements from BA, CA and FA samples

The elements that presented the highest enrichment in the bottom ash sample (BA) and, therefore, presented low volatility are $\mathrm{K}$ and $\mathrm{Mg}$. Sulfur showed impoverishment for all ash samples, indicating that most part of this element is emitted together with the flue gases. Some variations among the enrichment factors determined for the ashes can be related to the affinity of some elements for the unburnt carbon content of the samples [29].

In order to complement the chemical composition study, the determination of total carbon content (TC) of CCBs was also performed (Table 6). Total carbon content was determined by a LECO analyzer.

Table 6 Total carbon content of coal ash samples (wt\%)

\begin{tabular}{cc}
\hline Samples & C (\%) \\
\hline BA & 26.83 \\
CA & 15.72 \\
FA & 3.05
\end{tabular}

According to Table 6, the total carbon content of CCBs follows the order: BA > CA > FA. That result was expected because BA sample had a shorter exposure time to the flue gases from the burning of coal when compared to the other samples and consequently has more remaining unburned carbon in it (as shown in Figure 1). On the other hand, particles which had a longer exposure time to the combustion gas presented lower total carbon content (Fly 
Table 7 Physicochemical properties of coal ashes generated at FTPP

\begin{tabular}{cccccccc}
\hline Sample & $\mathrm{pH}$ & $\mathrm{C}(\mu \mathrm{S})$ & $\begin{array}{c}\text { Loss on } \\
\text { Ignition }(\%)\end{array}$ & $\begin{array}{c}\text { Bulk Density } \\
\left(\mathrm{g} \mathrm{cm}^{-3}\right)\end{array}$ & $\begin{array}{c}\mathrm{S}_{\mathrm{BET}} \\
\left(\mathrm{m}^{2} \mathrm{~g}^{-1}\right)\end{array}$ & $\begin{array}{c}\text { External surface area } \\
\left(\mathrm{m}^{2} \mathrm{~g}^{-1}\right)\end{array}$ & $\begin{array}{c}\text { CEC } \\
\left(\mathrm{meq}^{-1}\right)\end{array}$ \\
\hline BA & 7.56 & 121.0 & 17.4 & 0.6 & 13.5 & 0.188 & 0.05 \\
CA & 7.58 & 138.0 & 13.9 & 0.8 & 11.5 & 0.234 & 0.07 \\
FA & 7.56 & 183.0 & 8.00 & 0.8 & 8.4 & 1.35 & 0.16 \\
\hline
\end{tabular}
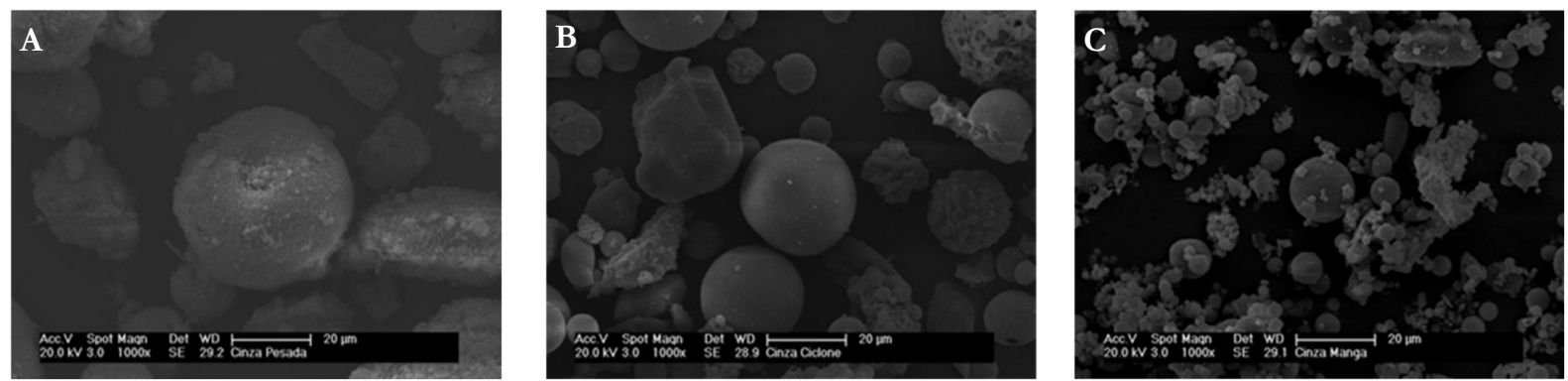

Fig. 8. Scanning Electron Micrographs (SEM) of coal ashes: a) BA; b) CA; c) FA.

ash sample - FA). Studying total carbon content in this CCBs samples is also important in order to compare these results, which reflect the power plant burning efficiency, with the new samples from the same power plant after its modernization.

\subsubsection{Physical and chemical characteristics}

The $\mathrm{pH}$ and conductivity obtained from coal ashes are given in Table 7 . The $\mathrm{pH}$ values of CCBs suspension were very close and presented alkaline characteristics due to the presence of cations of both alkali and alkaline earth metals (showed previously in Table 5) in the ashes, similar to the results reported by other researchers $[8,37,38]$.

The conductivity values of fly ashes suspension were $121,0 \mu \mathrm{S}, 138 \mu \mathrm{S}$, and $183,0 \mu \mathrm{S}$, for $\mathrm{BA}, \mathrm{CA}$, and $\mathrm{FA}$, respectively. This crescent order is related to the decreasing order of particle size for the different CCBs (shown posteriorly in the morphology study in Figure 8 and confirmed in the particle size analysis at item 3.2.7). Because fly ash sample (FA) has the smallest particle size, some compounds present in its chemical composition (showed in Table 5) as As, $\mathrm{Ba}, \mathrm{Cr}, \mathrm{Cu}, \mathrm{Mo}$, and $\mathrm{Sr}$, can undergo dissolution easier than the samples with higher particle sizes, conferring its suspension higher conductivity. These results are in accordance with other studies reported the values of conductivity for different Brazilian fly ashes $[7,8]$.

It should be noted that the ashes with the lowest total carbon contents (FA and CA - Table 6) also presented higher conductivity values. [7] explains that as the carbon content gets lower, the level of solubilization of the other elements gets higher, what is in accordance with this study.

As shown in Table 7, the values of loss on ignition for CCBs followed the same decreasing order of TC (BA $>$ CA $>$ FA - Table 6), confirming that the sample with a shorter exposure time to the heat gases from the power plant furnace, the bottom ash sample (BA), was less burnt than the other two samples, and therefore presented higher loss on ignition.

According to Table 7, bulk density was very similar to all samples, but it was slightly lower for BA. Because BA sample presents higher particle size, it occupies a higher volume for the same sample weight, conferring it lower density when compared to the other two samples. In addition, BA also presented higher content of carbon, that besides being a light element, it also confers a greater porosity to the sample, giving it less weight for a given volume.

The specific surface area $\left(S_{\mathrm{BET}}\right)$ determined by a Micromeritics Adsorption Analyzer, and the external surface area, obtained by a laser diffraction particle size analyzer were both obtained for CCBs and, are also given in Table 7. The decreasing order of the specific surface area values $(B A>C A>F A)$ suggests that the porosity of materials increases with the content of carbon, resulting in higher internal surface areas and consequently higher total surface areas (BET area). On the other hand, when only the external surface area is considered, its values will vary depending on particles size. Therefore, external surface area increases with the increasing of particle size according to the order: BA $\left(0.188 \mathrm{~m}^{2} \mathrm{~g}^{-1}\right)<\mathrm{CA}\left(0.234 \mathrm{~m}^{2} \mathrm{~g}^{-1}\right)<\mathrm{FA}\left(1.35 \mathrm{~m}^{2}\right.$ $\mathrm{g}^{-1}$ ). The cation exchange capacity results (CEC - Table 7) show that the values for the CCBs were $0.05,0.07$ and 0.16 meq $\mathrm{g}^{-1}$ for the BA, CA and FA samples, respectively. These results suggest that the smaller the particle size for an ash sample and the larger its external surface area (observed for FA sample), the higher the capacity of the material for the cations exchange.

\subsubsection{Morphology}

The scanning electron micrographs (SEM) of the coal combustion by-products increased by $1000 \mathrm{X}$ and determined by a scanning electron microscope are shown in Figure 8. Coal fly ash particles typically had the predominance of spherical shapes at different sizes, which is a result of the burning of the coal in the pulverized form. This morphology is similar to previous observations in other researches [4, 21, 38, 39]. Different physical states of silica are responsible for the particles of irregular size [39]. According to Figure 8, in general, the particles size of the samples followed the decreasing order: $\mathrm{BA}>\mathrm{CA}>\mathrm{FA}$. As previously mentioned, the size of the particles of each type of 
ash is related to the specific ash retention system and how long each residue was exposed to the flue gas after the combustion of coal. Thus, all the differences between the CCBs related to the total carbon content, loss on ignition and external surface area can be also explained.

\subsubsection{Mineralogical composition}

Crystalline phases identified for the ash samples and determined by X ray diffraction (XRD) are shown in Figure 9. The three ash samples are composed mainly of quartz, mullite, and magnetite (which are also confirmed from their chemical compositions - Table 5). These crystalline phases are typically encountered in this type of material and were identified in other studies [21, 40-44]. The differences between the relative intensities of the XRD patterns may indicate different ratio for the phases as well as may be the result of sample preparation [4]. All diffractograms also presented the amorphous phase, which can be attributed to the amorphous silica content in these materials. Table 8 shows the XRD patterns and the chemical formulas of each crystalline phase identified in the CCBs.

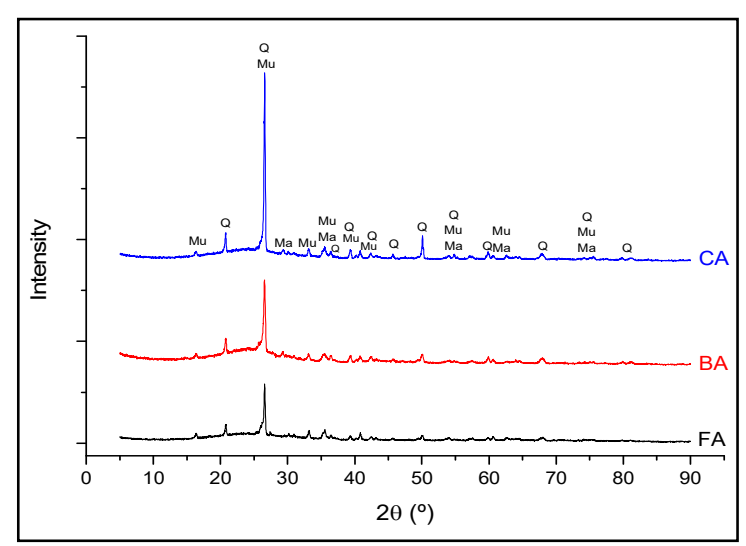

Fig. 9. $\mathrm{XRD}$ Patterns of coal ash samples $(\mathrm{Q}=\mathrm{Quartz}, \mathrm{M}=$ Mullite and $\mathrm{Ma}=$ Magnetite)

Table 8 XRD Patterns and chemical formulas of the different crystalline phases identified in the coal ash samples

\begin{tabular}{ccc}
\hline $\begin{array}{c}\text { Crystalline } \\
\text { Phases }\end{array}$ & $\begin{array}{c}\text { XRD } \\
\text { Pattern }\end{array}$ & $\begin{array}{c}\text { Chemical } \\
\text { formula }\end{array}$ \\
\hline Quartz $(\mathrm{Q})$ & $83-539$ & $\mathrm{SiO}_{2}$ \\
Mullite $(\mathrm{Mu})$ & $89-2645$ & $\mathrm{Al}_{4,8} \mathrm{Si}_{1,2} \mathrm{O}_{9,6}$ \\
Magnetite $(\mathrm{Ma})$ & $89-691$ & $\mathrm{Fe}_{3} \mathrm{O}_{4}$ \\
\hline
\end{tabular}

According to Figure 2, quartz is also present in the precursor coal and did not change its crystalline form under the power plant burning conditions. On the other hand, mullite and magnetite were formed after some mineralogical modifications of kaolinite and pyrite from the feed coal, respectively (Figure 2), after the combustion process. Table 9 shows the percentages (by \% weight) of the different crystalline phases of the CCBs, obtained by the Rietveld Method.

As explained before, the mass percentages obtained by the Rietveld Method were calculated without the amorphous phase, only for comparison between the samples. According to Table 9, the mass percentages of the different crystalline phases had small variations among the samples. The highest contents were quartz and mullite for all the ashes. The differences between the phase quantities can be attributed to the different temperatures that the residues were when they were collected from each waste retention system.

Table 9 Percentages by weight from different crystalline phases of CCBs obtained by Rietveld Method

\begin{tabular}{cccc}
\hline Sample & $\begin{array}{c}\text { Quartz } \\
(\%)\end{array}$ & $\begin{array}{c}\text { Mullite } \\
(\%)\end{array}$ & $\begin{array}{c}\text { Magnetite } \\
(\%)\end{array}$ \\
\hline BA & 47.0 & 49.0 & 4.0 \\
CA & 57.0 & 40.3 & 2.7 \\
FA & 47.11 & 48.7 & 4.2 \\
\hline
\end{tabular}

\subsubsection{Identification of functional groups}

The functional groups present in the CCBs samples and identified by FTIR absorption spectroscopy technique are shown in Figure 10. The three samples presented very similar infrared spectra, with an intense and wide band close to $3446.07 \mathrm{~cm}^{-1}$ related to the axial deformations of $\mathrm{O}-\mathrm{H}$ bonds, which can be attributed to water. Angular stretches and angular deformations in a band at $2925.38 \mathrm{~cm}^{-1}$ and in a peak at $1384.55 \mathrm{~cm}^{-1}$, respectively, related to $\mathrm{C}-\mathrm{H}$ bonds of organic groups were also found. Similarly to the infrared spectra of feed coal (Figure 4), the bands at $1077.14 \mathrm{~cm}^{-1}$ and $543.81 \mathrm{~cm}^{-1}$ could be assigned to characteristic bonds of $\mathrm{O}-\mathrm{Si}-\mathrm{O}$ groups, for axial and angular deformations, respectively. The FTIR spectra also showed characteristic frequencies of symmetrical stretching vibrations of O-T-O groups (close to $777.4 \mathrm{~cm}^{-1}$ ) and also angular deformation vibrations of the same group at $454.64 \mathrm{~cm}^{-1}$, where $\mathrm{T}$ can represent $\mathrm{Si}$ or $\mathrm{Al}$, related to the crystalline phases of quartz and mullite (previously identified by XRD - Figure 9) or may indicate the presence of amorphous aluminosilicates. These results are in accordance to [12] and [14] who identified the functional groups of Brazilian coal ashes, as well as to [45], who identified the functional groups of foreign ashes.

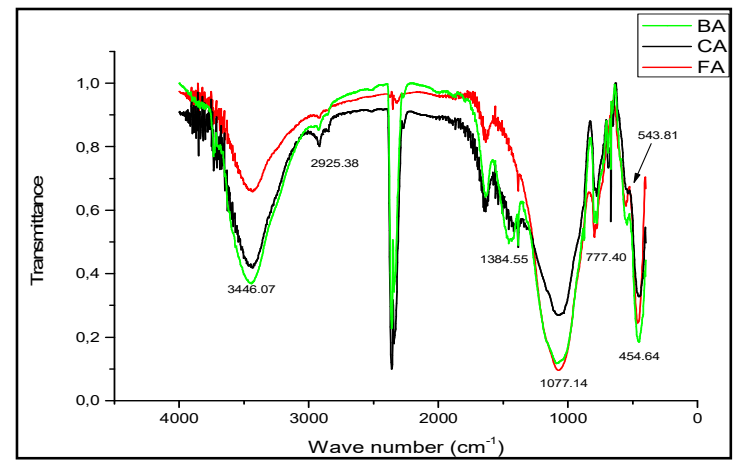

Fig. 10. FTIR spectra of coal ash samples

By comparing the feed coal and the CCBs FTIR spectra (Figures 4 and 10, respectively), it can be noted that the intensities of peaks and bands related to the bonds of carbon compounds were reduced, showing the reduction of organic matter in the ashes after the coal combustion [46]. On the other hand, the band close to $1030 \mathrm{~cm}^{-1}$ was extended, indicating an increase in the vibrational modes of 
the O-Si-O bonds, which shows that those elements in the ashes can take other combination when feed coal is burnt (such as mullite formation or the presence of amorphous phase formed after the silicon fusion).

\subsubsection{Thermal analysis}

The thermal analysis of the CCBs was carried out in order to understand the relationship between the contents of moisture, organic matter, inorganic matter and residual carbon, as well as to verify the stability of the compounds in the ashes. The TGA and DTG diagrams of BA, CA, and FA samples were evaluated by Thermo Gravimetric Analysis (TGA) using the TGA thermogravimetric analyzer and, are shown in Figures 11, 12 and 13, respectively.

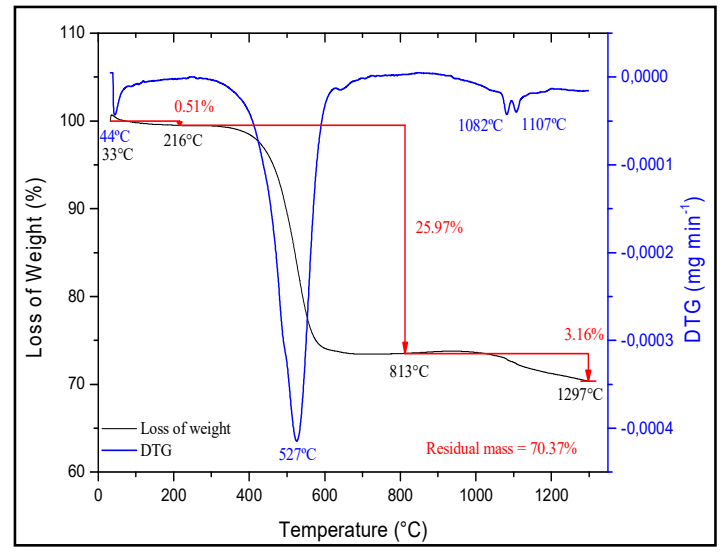

Fig. 11. TGA-DTG diagrams of bottom ash sample (BA).

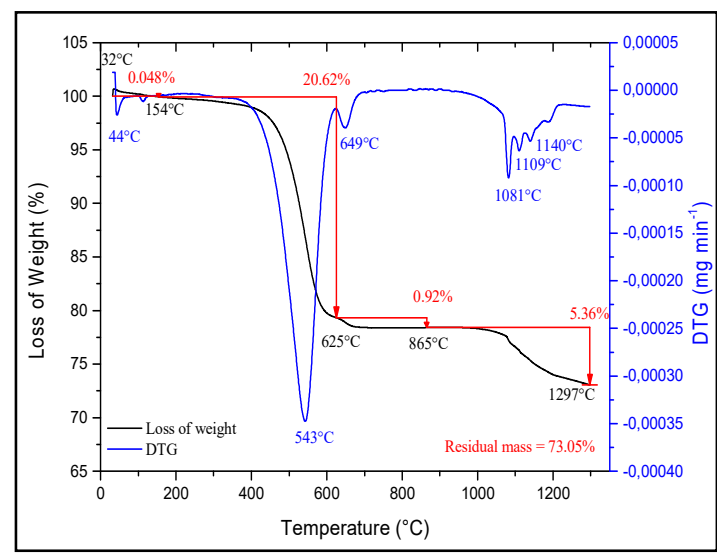

Fig. 12. TGA-DTG diagrams of cyclone ash sample (CA).

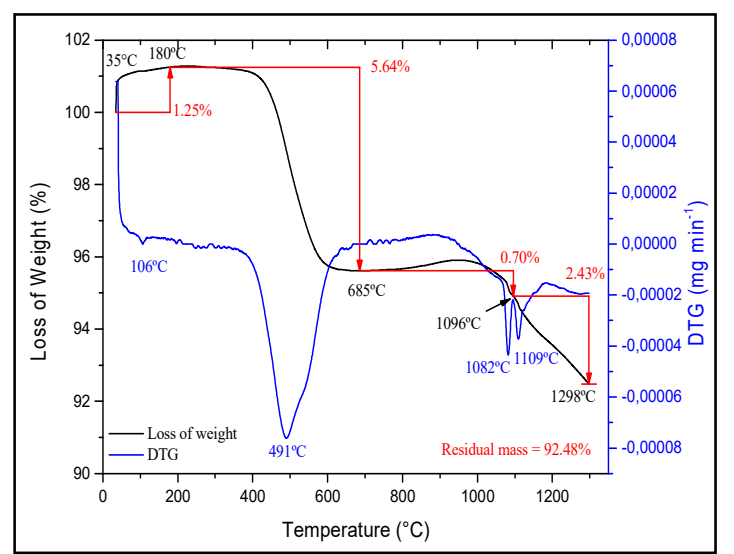

Fig. 13. TGA-DTG diagrams of fly ash sample from bag filter (FA).
BA sample (Figure 11) presented a small loss of weight related to moisture loss $(0.51 \%)$, followed by a loss of $25.97 \%$ related to the organic matter, between $216^{\circ} \mathrm{C}$ e $813^{\circ}$ C. The loss of organic matter is clearly shown in the DTG curve at $527^{\circ} \mathrm{C}$, and can be related to the total carbon content showed before for BA sample (26.83\% - Table 6). The loss of weight between $813^{\circ} \mathrm{C}$ e $1297^{\circ} \mathrm{C}(3.16 \%)$ can be attributed to the degradation of the organic compounds as well as the pyrolysis of the residual carbon. The residual mass content related to the inorganic compounds was $70.37 \%$.

TGA and DTG curves for CA sample (Figure 12) were very similar to those of BA sample. The decrease in weight related to moisture loss was $0.048 \%$, followed by a loss of $20.62 \%$ related to volatile material, between $154^{\circ} \mathrm{C}$ and $625^{\circ}$ C. The losses of weight related to the degradation of the organic compounds as well as that related to the pyrolysis of the residual carbon were $0.92 \%$ and $5.36 \%$, respectively (between $625^{\circ} \mathrm{C}$ e $1297^{\circ} \mathrm{C}$ ). The residual mass of CA sample (73.05\%), related to inorganic compounds content, was higher than that presented for BA sample. This result was expected once the cyclone ash sample was exposed a long time to the combustion gases than BA.

FA sample presented a different thermal behavior than the other two ashes. As shown in Figure 13, initially there was a mass increase of $1.25 \%$ (up to $180^{\circ} \mathrm{C}$ ), probably resulting from the interaction between the nitrogen used in the analysis and the sample through adsorption and absorption phenomena. This interaction between sample and analysis atmosphere is possible since FA sample has very small particles when compared to the other ash samples. The weight loss of $5.64 \%$, related to both organic matter and incorporated nitrogen occurred between $180^{\circ} \mathrm{C}$ e $685^{\circ} \mathrm{C}$. In addition to the loss of weight related to the degradation of the organic compounds and the residual carbon pyrolysis (between $685^{\circ} \mathrm{C}$ e $1298^{\circ} \mathrm{C}$ ), there was also a change in the sample clearly showed when DTG curve fell at $1082^{\circ} \mathrm{C}$ and $1109^{\circ} \mathrm{C}$, which can be attributed to a change in the fly ash compounds structure, once the TGA curve had a constant loss of weight. The residual mass of FA was, as expected, higher than the others $(92.48 \%)$ and it is in accordance with the result of its loss on ignition ( $8 \%$ - Table 7$)$. It is important to note that FA sample melted around $900^{\circ} \mathrm{C}$. This could happen because of the interaction and aggregation of small particles of FA, which allow the easier heat propagation when subjected to high temperatures.

Residual masses of feed coal (FC) and BA, CA and FA ash samples (Figures 5, 11, 12 and 13, respectively), shown in thermal analysis study decreased in the following order: $\mathrm{FA}>\mathrm{CA}>\mathrm{BA}>\mathrm{FC}$. These results corroborate to the previous results of loss on ignition (LOI) and total carbon content (TC) because of the different degrees of burn for each sample, as explained before.

\subsubsection{Particle size analysis}

The type and the efficiency of each ash retention system of a thermal coal-fired power plant are very important factors to determine the size of particles of each solid waste, whether bottom, light or fly ashes. The results of the particle size distribution of BA, CA and FA samples 
determined by a laser diffraction particle size analyzer can be observed in both Figures 14, 15 and 16, respectively and Table 10.

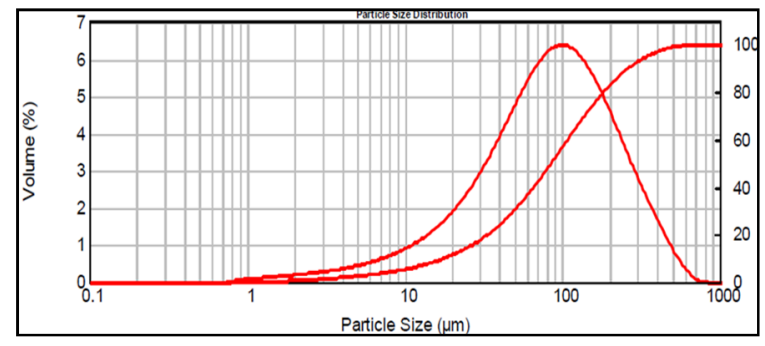

Fig. 14. Particle size distribution of bottom ash sample (BA).

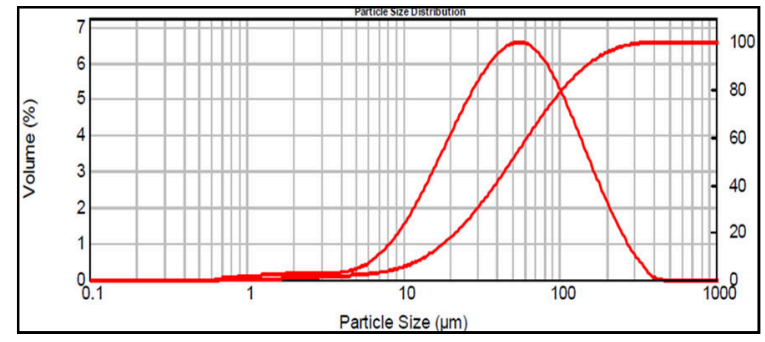

Fig. 15. Particle size distribution of cyclone ash sample (CA).

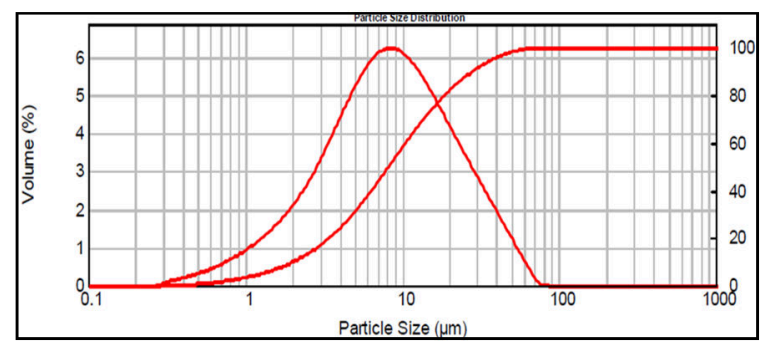

Fig. 16. Particle size distribution of fly ash sample from bag filter (FA).

Table 10 Particle size distribution analysis of coal ash samples

\begin{tabular}{cccccc}
\hline & \multicolumn{5}{c}{ Particle size distribution analysis } \\
\cline { 2 - 6 } Samples & $\mathrm{D}_{3.2}$ & $\mathrm{D}_{4.3}$ & $\mathrm{D}_{10}$ & $\mathrm{D}_{50}$ & $\mathrm{D}_{90}$ \\
& $(\mu \mathrm{m})$ & $(\mu \mathrm{m})$ & $(\mu \mathrm{m})$ & $(\mu \mathrm{m})$ & $(\mu \mathrm{m})$ \\
\hline BA & 31.87 & 116.6 & 17.53 & 84.60 & 260.32 \\
CA & 25.63 & 67.77 & 14.12 & 49.34 & 147.70 \\
FA & 4.44 & 12.03 & 2.018 & 8.16 & 27.78
\end{tabular}

OBS: $D_{10}$ refers to the diameter above which $10 \%$ of the particles are present.

The shape of the curves observed in Figures 14, 15 and 16 shows that the particle size distribution follows a normal distribution, thus the average particle diameter of $\mathrm{BA}, \mathrm{CA}$ and FA samples can be considered to be close to $D_{50}$, and therefore are around $84.600 \mu \mathrm{m}, 49.348 \mu \mathrm{m}$ and $8.167 \mu \mathrm{m}$, respectively. The $\mathrm{D}_{3.2}$ and $\mathrm{D}_{4.3}$ diameter values, calculated by the equipment and based on the average surface area of the particles and on the average volume of the particles (very important to design particles retention equipment), respectively, are shown in Table 10. The size of particles is in accordance with the scanning electron micrographs results (Figure 8) and thus decreased as follows: $\mathrm{BA}>\mathrm{CA}>\mathrm{FA} . \mathrm{D}_{10}$ values confirm that the smallest particles are in FA sample, as before discussed.

The particle size range for BA sample was between 0.9 and $796 \mu \mathrm{m}$. For that sample, the largest particle size (796 $\mu \mathrm{m})$ is the same as the maximum particle size value of feed coal (shown in item 3.1), indicating that feed carbon particles can be directed to the bottom of the boiler furnace without being burnt during the combustion, thus indicating that the FTPP has low burn efficiency. In addition, BA also has the largest specific area (BET) due to its high unburnt carbon content and, consequently, a higher loss on ignition, as shown before. $\mathrm{D}_{90}$ values show that $90 \%$ of the particles of BA, CA and FA samples have diameters smaller than $260.323 \mu \mathrm{m}, 147.704 \mu \mathrm{m}$, and $27.786 \mu \mathrm{m}$, respectively, which also corroborates to the previous results.

\subsubsection{Leaching and solubilization tests}

The concentration of the chemical elements in the ash extracts of the leaching tests (using acetic acid) and solubilization tests (using water) were determined by inductively coupled plasma optical emission spectrometry (ICP-OES), and are shown in Tables 11 and 12, respectively. The results complement the characterization study of these materials. According to [14], the chemical elements chosen for these tests are those that represent the highest risk to fauna and flora and it is also being used to evaluate the environmental behavior of waste materials.

According to Table 11, FA sample was the only one that presented in the leachate solution a concentration (for As) above the allowed limit by Brazilian regulation $(1.27 \mathrm{mg}$ $\mathrm{L}^{-1}$, while the limit is $\left.1.0 \mathrm{mg} \mathrm{L}^{-1}\right)$. Thus, the FA sample is considered hazardous and can be classified as Class I, while CA and BA samples can be classified as Class II (non-hazardous waste). Therefore, the disposal of the ash from the bag filter should be carried out after treatment or be carefully disposed of in industrial landfills designed to handle hazardous waste in order to avoid contamination on site.

The solubilization test complements the leaching study and classifies non-hazardous waste as inert or non-inert by NBR 10006 [25]. This study was performed for all samples (including FA) for comparison. According to the results showed in Table 12, all samples presented concentration values for $\mathrm{Al}$ and As above the allowed limit, whereas only for BA sample the extracted solution also presented high concentrations of $\mathrm{Cr}$ and $\mathrm{Fe}$. It is noteworthy that, when the lead concentration was considered, it was not possible to classify the wastes in the solubilized extract (Table 12), since the equipment detection limit is above the limit of the Brazilian regulation.

$\mathrm{Hg}$ determination was below the equipment detection limit (Tables 11 and 12). According to [7], the determination of mercury can be impaired due to the absence of an oxidizing agent in the solution able to stabilize this element, as well as due to the increase of temperature in the solution caused by the stirring of suspension during the tests. The classification of the tested materials is summarized in Table 13. 
Table 11 Concentration of elements leachated from fly ashes and the allowed limit values

\begin{tabular}{ccccc}
\hline \multirow{2}{*}{ Elements } & \multicolumn{3}{c}{ Concentration $\left(\mathrm{mg} \mathrm{L}^{-1}\right)$} & \multirow{2}{*}{ Maximum Limits $\left(\mathrm{mg} \mathrm{L}^{-1}\right)$} \\
\cline { 2 - 4 } $\mathrm{Ag}$ & $<0.010$ & $\mathrm{CA}$ & $\mathrm{FA}$ & 5.0 \\
$\mathrm{As}$ & $0.086 \pm 0.001$ & $0.111 \pm 0.002$ & $1.27 \pm 0.2$ & 1.0 \\
$\mathrm{Ba}$ & $0.236 \pm 0.001$ & $0.161 \pm 0.001$ & $0.0269 \pm 0.0002$ & 70 \\
$\mathrm{Cd}$ & $0.0266 \pm 0.0002$ & $0.031 \pm 0.001$ & $0.2731 \pm 0.0001$ & 0.5 \\
$\mathrm{Cr}$ & $<0.01$ & $0.014 \pm 0.001$ & $0.039 \pm 0.0004$ & 5.0 \\
$\mathrm{Hg}$ & $<0.001$ & $<0.001$ & $<0.001$ & 0.1 \\
$\mathrm{~Pb}$ & $0.0527 \pm 0.0003$ & $0.0527 \pm 0.0003$ & $0.047 \pm 0.002$ & 1.0 \\
$\mathrm{Se}$ & $0.107 \pm 0.01$ & $0.13 \pm 0.2$ & $0.138 \pm 0.002$ & 1.0 \\
\hline
\end{tabular}

$\left(^{*}\right)$ Established by Norm ABNT NBR 10004 (2004a).

Table 12 Concentration of elements solubilized from fly ashes and the allowed limit values

\begin{tabular}{ccccc}
\hline \multirow{2}{*}{ Elements } & \multicolumn{3}{c}{ Concentration $\left(\mathrm{mg} \mathrm{L}^{-1}\right)$} & Maximum Limits $\left(\mathrm{mg} \mathrm{L}^{-1}\right)$ \\
\cline { 2 - 5 } $\mathrm{Ag}$ & $<0.010$ & $\mathrm{CA}$ & $<0.010$ & 0.05 \\
$\mathrm{Al}$ & $3.4 \pm 0.04$ & $0.79 \pm 0.05$ & $0.27 \pm 0.01$ & 0.2 \\
$\mathrm{As}$ & $9.95 \pm 0.2$ & $0.17 \pm 0.01$ & $0.7 \pm 0.03$ & 0.01 \\
$\mathrm{Ba}$ & $0.038 \pm 0.001$ & $0.15 \pm 0.01$ & $0.022 \pm 0.001$ & 0.7 \\
$\mathrm{Cd}$ & $<0.01$ & $<0.01$ & $<0.01$ & 0.005 \\
$\mathrm{Cr}$ & $0.36 \pm 0.01$ & $<0.01$ & $0.042 \pm 0.003$ & 0.05 \\
$\mathrm{Cu}$ & $<0.05$ & $0.074 \pm 0.005$ & $<0.05$ & 2 \\
$\mathrm{Fe}$ & $0.376 \pm 0.005$ & $0.31 \pm 0.06$ & $<0.1$ & 0.3 \\
$\mathrm{Hg}$ & $<0.001$ & $<0.001$ & $<0.001$ & 0.001 \\
$\mathrm{Mn}$ & $0.013 \pm 0.001$ & $0.027 \pm 0.008$ & $<0.01$ & 0.1 \\
$\mathrm{Na}$ & $190.5 \pm 0.2$ & $92 \pm 2$ & $77 \pm 3$ & 200 \\
$\mathrm{~Pb}$ & $<0.1$ & $<0.1$ & $<0.1$ & 0.01 \\
$\mathrm{Se}$ & $0.43 \pm 0.03$ & $0.045 \pm 0.001$ & $0.039 \pm 0.001$ & 0.01 \\
$\mathrm{Zn}$ & $0.093 \pm 0.003$ & $0.21 \pm 0.001$ & $<0.1$ & 5 \\
\hline
\end{tabular}

Table 13 Summary of the classification of wastes from coal combustion according to NBR 10005 and 10006 [24, 25].

\begin{tabular}{ccc}
\hline Sample & Leaching test & Solubilization tests \\
\hline \multirow{2}{*}{ BA } & Class II - Non- & Non-Inert - Class \\
& Hazardous & II A \\
CA & Class II - Non- & Non-Inert - Class \\
& Hazardous & II A \\
FA & Class I - & - \\
\hline
\end{tabular}

According to Table 13, although BA and CA samples are considered non-hazardous, they are also non-inert, thus they should be disposed of in landfills or co-processed. It is worth mentioning, as explained by [47], that coal ashes are not completely inert and can, over time, mobilize trace elements of their mineral fraction. Therefore, stabilization and immobilization studies of toxic elements present in this type of waste are needed in future research.

\section{CONCLUSIONS}

Feed coal from Figueira Thermal Power Plant (FTPP) presented $72.2 \%$ of volatile matter, of which $55.32 \%$ corresponded to the total carbon content. LOI, FTIR, TGA and TC results were correlated and confirmed these results. The main mineral phases found in FC and determined by XRD were quartz, kaolinite, and pyrite. XRF and FTIR techniques were also used to confirm those results. Particle size distribution results, related to the burning efficiency in coal-fired power plants followed a normal distribution, with a $\mathrm{D}_{50}$ of $43.357 \mu \mathrm{m}$. Elements as $\mathrm{As}, \mathrm{Cr}, \mathrm{Ni}$, and $\mathrm{Pb}$ were found in FC sample, indicating that the burning of the feed coal should be monitored due to the toxic potential of those elements.

Coal combustion by-products (CCBs) presented similar chemical composition, with a total content of the main oxides $\left(\mathrm{SiO}_{2}, \mathrm{Al}_{2} \mathrm{O}_{3}\right.$, and $\left.\mathrm{Fe}_{2} \mathrm{O}_{3}\right)$ above $72 \%$ for the three samples, and were classified as class $\mathrm{F}$ according to ASTM. Ashes enrichment factor analysis showed that As, $\mathrm{Zn}$, and $\mathrm{Pb}$ concentrate mainly in fly ash from bag filter (FA), whereas the elements that presented higher enrichment in the bottom ash (BA) and therefore present low volatility are $\mathrm{K}$ and $\mathrm{Mg}$. All ashes presented quartz, mullite, and magnetite as crystalline phases as well as the same functional groups, which indicated contents of humidity, organic matter and $\mathrm{Si}$ and $\mathrm{Al}$ compounds. The XRD, XRF, TGA, FTIR LOI, and TC technique 
complemented themselves to confirm the results. Total Carbon content (TC) of CCBs samples decreased in the following order: BA $(26.83 \%)>$ CA $(15.72 \%)>$ FA (3.05\%). These contents were related to the surface area, TGA, LOI, particle size analysis, and SEM results. Also, all $\mathrm{CCBs}$ presented similar $\mathrm{pH}$ and conductivity values. Those results were related to the chemical composition, Enrichment Factor (EF), particle size analysis, LOI, and external and total surface areas.

Cation Exchange Capacity (CEC) results for the ashes followed the increasing order: $\mathrm{BA}<\mathrm{CA}<\mathrm{FA}$ and showed a relationship with both the particle size analysis and the external surface areas. CCBs showed a very similar particle size distribution and, all results were in accordance with external surface area values and morphology. Leaching and solubilization tests of CCBs showed that FA sample was considered hazardous and classified as class I waste, while $\mathrm{CA}$ and BA samples were considered non-hazardous and non-inert wastes and classified as class II-A. Therefore, FA disposal should be done after treatment or very strict criteria conditions for its disposal needs to be followed.

Stabilization and immobilization studies of toxic elements present in ashes are needed in future research in order to avoid contamination on waste disposal site. In addition to contributing to the understanding of the relationship between coal and its combustion products, this work can also help to reduce the environmental impacts caused by the CCBs disposal, as well as can also be used to compare the characteristics of CCBs from FTPP with the new wastes that will be generated by the same thermal power plant that will be soon modernized.

\section{AUTHOR INFORMATION}

Corresponding Author

*Email: Julianaizidoro@usp.br

\section{ORCID (1)}

Shaobin Wang : 0000-0002-1751-9162

\section{ACKNOWLEDGEMENTS}

The authors gratefully acknowledge the Companhia Paranaense de Energia (COPEL) for the financial support in carrying out this research. We also acknowledge Figueira Thermal Power Plant, located in southern Brazil, for the assistance in collecting coal and ash samples, besides technical visits. We acknowledge Professor Nelson Batista de Lima and Renê Ramos de Oliveira for the assistance in the X-ray diffraction analysis as well as Sergio Carvalho Moura for the assistance with total carbon analysis. Thanks also go to Dr. Ivana Conte Cosentino from Materials Science and Technology Center, Nuclear and Energy Research Institute, for assistance in the operation of BET Surface area Analyser equipment and Celso Vieira de Morais for the assistance with SEM data acquisition.

\section{REFERENCES}

[1] Dudley, B., BP statistical review of world energy. London, UK, 2012.

[2] Aneel, B.d.I.d.G., Agência Nacional de Energia Elétrica. Brasília. Decreto, 2012(5143).
[3) Flores-Lopes, F. And L.R. Malabarba, Uso De Índices Ecológicos Emtaxocenoses De Peixes No Monitoramento Ambiental-Estudo De Caso Da Bacia Hidrográfica Do Lago Guaíba, Rs, Brasil. Fábio Flores Lopes, 2006: p. 171.

[4] Izidoro, J.d.C., Síntese e caracterização de zeólita pura obtida a partir de cinzas volantes de carvão. 2013, Universidade de São Paulo.

[5] Rohde, G.M. and O. Zwonok, Cinzas de carvão fóssil no Brasil: aspectos técnicos e ambientais. 2006: Cientec.

[6] Kalkreuth, W., et al., Evaluation of environmental impacts of the Figueira coal-fired power plant, Paraná, Brazil. Energy Exploration \& Exploitation, 2014. 32(3): p. 423-469.

[7] Depoi, F.S., D. Pozebon, and W.D. Kalkreuth, Chemical characterization of feed coals and combustion-by-products from Brazilian power plants. International Journal of Coal Geology, 2008. 76(3): p. 227-236.

[8] Izidoro, J.d.C., et al., Characteristics of Brazilian coal fly ashes and their synthesized zeolites. Fuel Processing Technology, 2012. 97: p. 38-44.

[9] Flues, M., et al., Radioactivity of coal and ashes from Figueira coal power plant in Brazil. Journal of Radioanalytical and Nuclear Chemistry, 2006. 270 (3): p. 597-602.

[10] Fungaro, D., J. Izidoro, and M. Bruno, Aplicação de material zeolítico sintetizado de cinzas de carvão como adsorvente de poluentes em água. Eclética Química, 2009.34(1): p. 45-50.

[11] Levandowski, J. and W. Kalkreuth, Chemical and petrographical characterization of feed coal, fly ash and bottom ash from the Figueira Power Plant, Paraná, Brazil. International Journal of Coal Geology, 2009. 77(3-4): p. 269-281.

[12] De Carvalho, T.E.M., D.A. Fungaro, and J.d.C. Izidoro, Adsorção do corante reativo laranja 16 de soluções aquosas por zeólita sintética. Química Nova, 2010. 33: p. 358-363.

[13] Fungaro, D.A., et al., Zeolite from fly ASH-iron oxide magnetic nanocomposite: synthesis and application as an adsorbent for removal of contaminants from aqueous solution. 2012.

[14] Fungaro, D., et al., Coal fly ash from brazilian power plants: chemical and physical properties and leaching characteristics, in Fly Ash: Sources, Applications and Potential Environmental Impacts. 2013, Nova Science Publishers. p. 145-164.

[15] Yamaura, M. and D.A. Fungaro, Synthesis and characterization of magnetic adsorbent prepared by magnetite nanoparticles and zeolite from coal fly ash. Journal of materials science, 2013. 48(14): p. 5093-5101.

[16] Fungaro, D.A. and C.P. Magdalena, Counterion Effects on the Adsorption of Acid Orange 8 from Aqueous Solution onto HDTMA-Modified Nanozeolite from Fly Ash. Environment and Ecology Research, 2014. 2(2): p. 97-106. 
[17] Cunico, P., A. Kumar, and D.A. Fungaro, Adsorption of dyes from simulated textile wastewater onto modified nanozeolite from coal fly ash. J Nanosci Nanoeng, 2015. 3: p. 148-161.

[18] Gonçalves, S.A., Ambientes institucional e técnico e esquemas interpretativos: o caso da Companhia Paranaense de Energia-COPEL. 1998.

[19] GOVERNO, D.P., Agência Estadual de Notícias (AEN). Museu Paranaense.

[20] Sassine, A., et al. Determinação de carbono em amostras de siliceto de urânio para reatores nucleares. in International Nuclear Atlantic Conference; Encontro Nacional de Fisica e Reatores Thermal Hidraulica.

[21] Umaña Peña, J.C., Síntesis de zeolitas a partir de cenizas volantes de centrales termoeléctricas de carbón. 2002: Universitat Politècnica de Catalunya.

[22] Wang, S. and Z. Zhu, Characterisation and environmental application of an Australian natural zeolite for basic dye removal from aqueous solution. Journal of hazardous materials, 2006. 136(3): p. 946-952.

[23] Fallavena, V.L., et al., Caracterização detalhada de material de referência certificado de carvão brasileiro. Quim. Nova, 2013.36(6): p. S1-S2.

[24] ABNT, N., 10005 (Associação Brasileira de Normas Técnicas-Norma Brasileira)(2004). Procedimento para obtenção de extrato lixiviado de resíduos sólidos. Rio de Janeiro, 2004.

[25] ABNT, N., 10004: 2004. Resíduos sólidos: Classificação. Associação Brasileira de Normas, 2004.

[26] Bizzo, W.A., Gestão de resíduos e gestão ambiental da indústria eletro-eletrônica. Universidade Estadual de Campinas (site), 2007.

[27] Flues, M., P. Hama, and A. Fornaro, Avaliação do nível da vulnerabilidade do solo devido à presença de termelétrica a carvão (Figueira, PR-Brasil). Química Nova, 2003. 26(4): p. 479-483.

[28] Pires, M. and X. Querol, Characterization of Candiota (South Brazil) coal and combustion by -product. International Journal of Coal Geology, 2004. 60(1): p. 57-72.

[29] Font, O., et al., Fate and abatement of mercury and other trace elements in a coal fluidised bed oxy combustion pilot plant. Fuel, 2012.95: p. 272-281.

[30] Wang, J., et al., Statistical analysis of the concent rations of trace elements in a wide diversity of coals and its implications for understanding elemental modes of occurrence. Fuel, 2008. 87(10-11): p. 2211-2222.

[31] Madrid Neto, J., Avaliação do impacto ambiental no solo dos terrenos adjacentes à usina termelétrica de Figueira/PR, devido à queima do carvão. 2010.

[32] Querol, X., et al., Synthesis of zeolites from coal fly ash: an overview. International Journal of coal geology, 2002. 50(1-4): p. 413-423.

[33] Ahmaruzzaman, M., A review on the utilization of fly ash. Progress in energy and combustion science, 2010. 36(3): p. 327-363.
[34] Ciocinta, R.C., et al., Optimization of the conditions for conversion of coal ash into zeolite material. Journal of Food, Agriculture \& Environment, 2013. 11(1): p. 1108-1112.

[35] Shigemoto, N., H. Hayashi, and K. Miyaura, Selective formation of $\mathrm{Na}-\mathrm{X}$ zeolite from coal fly ash by fusion with sodium hydroxide prior to hydrothermal reaction. Journal of materials science, 1993. 28(17): p. 4781-4786.

[36] Fulkerson, W. Proceedings of the first annual NSF Trace Contaminants Conference held at Oak Ridge National Laboratory, August 8-10, 1973. in NSF Trace Contaminants Conference 1973: Oak Ridge National Laboratory). 1974. Tenn.

[37] Ferret, L.S., Zeólitas de cinzas de carvão: síntese e uso. 2004.

[38] Paprocki, A., Síntese de zeólitas a partir de cinzas de carvão visando sua utilização na descontaminação de drenagem ácida de mina. 2009.

[39] Sarbak, Z., A. Stańczyk, and M. Kramer-Wachowiak, Characterisation of surface properties of various fly ashes. Powder Technology, 2004. 145(2): p. 82-87.

[39] Jha, V.K., M. Matsuda, and M. Miyake, Resource recovery from coal fly ash waste: an overview study. Journal of the ceramic society of Japan, 2008. 116 (1350): p. 167-175.

[40] Jha, V.K., M. Matsuda, and M. Miyake, Resource recovery from coal fly ash waste: an overview study. Journal of the ceramic society of Japan, 2008. 116 (1350): p. 167-175.

[41] Lee, K.-M. and Y.-M. Jo, Synthesis of zeolite from waste fly ash for adsorption of $\mathrm{CO} 2$. Journal of Material Cycles and Waste Management, 2010. 12(3): p. 212-219.

[42] Ibáñez, J., et al., Quantitative Rietveld analysis of the crystalline and amorphous phases in coal fly ashes. Fuel, 2013. 105: p. 314-317.

[43] Widiastuti, N., et al., Synthesis of zeolite X-carbon from coal bottom ash for hydrogen storage material. Advanced Materials Letters, 2014. 5(8): p. 453-458.

[44] Yu, J., et al., The synthesis and application of zeolitic material from fly ash by one-pot method at low temperature. Green Energy \& Environment, 2016. 1 (2): p. 166-171.

[45] Bieniek, J., A. Ściubidło, and I. Majchrzak-Kucęba, Properties of fly ash derived from coal combustion in air and in oxygen enriched atmosphere in a pilot plant instalation Oxy-Fuel CFB $0,1 \mathrm{MW}$. Energetyka, 2013(11): p. 821--826.

[46] Skoog, D.A., et al., Princípios de análise instrumental. 2002.

[47] Querol, X., et al., Mobility of trace elements from coal and combustion wastes. Fuel, 1996. 75(7): p. 821-838. Attriution 4.0 International License. 